\title{
Membrane-bound estrogen receptor-a expression and epidermal growth factor receptor mutation are associated with a poor prognosis in lung adenocarcinoma patients
}

\author{
Katsuhiko Shimizu*, Yuji Hirami, Shinsuke Saisho, Takuro Yukawa, Ai Maeda, Koichiro Yasuda and Masao Nakata
}

\begin{abstract}
Background: The purpose of this study is to clarify the correlations between the expression of membrane-bound estrogen receptor-a ( $m E R a)$ and epidermal growth factor receptor (EGFR) mutation and clinicopathological factors, especially in relation to the prognosis, in patients with lung adenocarcinoma.

Methods: We conducted a retrospective review of the data of 51 lung adenocarcinoma patients with tumors measuring less than $3 \mathrm{~cm}$ in diameter. Immunohistochemical staining for mERa expression and detection of the EGFR mutation status were performed.

Results: Among the 51 patients, the tumors in 15 showed both mERa expression and EGFR mutation. ("double positive") Significant associations between "double positive" and vascular invasion, vascular endothelial growth factor expression, and Ki-67 expression were observed. A multivariate analysis revealed that only "double positive" was an independent risk factor influencing the recurrence-free survival.
\end{abstract}

Conclusions: Presence of mERa expression together with EGFR mutation was found to be an independent prognostic factor for survival in patients with lung adenocarcinoma, suggesting cross-talk between $\mathrm{mERa}$ and EGFR mutation.

Keywords: Membrane-bound estrogen receptor-a, Epidermal growth factor receptor mutation, Lung adenocarcinoma

\section{Background}

Lung cancer is a leading cause of cancer-related death worldwide. The recent increase in interest in lung cancer appears to be attributable to the marked increase in the global prevalence of adenocarcinoma. Especially, adenocarcinoma appears to have a predilection for women, and the association of adenocarcinoma with a smoking habit may be less than that for the other histological subtypes of lung cancer [1,2]. These features of lung adenocarcinoma suggest that some factors peculiar to sex may be involved in the clinicopathology of this

\footnotetext{
* Correspondence: kshimizu@med.kawasaki-m.ac.jp

Department of General Thoracic Surgery, Kawasaki Medical School, Kurashiki, Okayama 701-0192, Japan
}

\section{Biomed Central

(c) 2012 Shimizu et al.; licensee BioMed Central Ltd. This is an Open Access article distributed under the terms of the Creative Commons Attribution License (http://creativecommons.org/licenses/by/2.0), which permits unrestricted use, distribution, and reproduction in any medium, provided the original work is properly cited. cancer, and some preference for female-associated pathways in the development of this form of lung cancer.

Estrogen exerts most of its effects in breast cancer via its receptors expressed in the tumor tissue; estrogen receptor (ER) $\alpha$ and $\beta$. In breast cancer, the expression of $E R \alpha$ is a useful marker that provides information on the patient prognosis and the potential efficacy of hormone therapy [3]. Since ER $\alpha$ and $\beta$ are also well known to be expressed in both normal lung epithelial cells and lung cancers, a possible role of estrogen has been proposed in lung carcinogenesis [4]. Known for decades, ER $\alpha$ is a nuclear steroid receptor that is expressed in breast, ovarian, and endometrial tissue, but antibodies used to detect $\mathrm{ER} \alpha$ in breast cancer show little or no reactivity in lung cancer tissues. On the other hand, non-nuclear (membrane-bound) ER $\alpha$ was described in 2002. Using this 
antibody that recognizes the ER $\alpha$ carboxy-terminus, staining was found in the cytoplasm and cell membrane [4]. This membrane-bound ER $\alpha$ comprises variant isoforms that lack the amino-terminus, because they cannot be detected by antibodies that recognize the ER $\alpha$ amino-terminus. In this study, we used this antibody for membrane-bound $\mathrm{ER} \alpha(\mathrm{mER} \alpha)$.

The other well known female-related factor is mutation of the epidermal growth factor receptor (EGFR). EGFR tyrosine kinase inhibitors (EGFR-TKIs) produce a dramatic clinical response in a significant proportion of patients with lung cancer [5]. In 2004, response to EGFR-TKIs was ascribed to the presence of some type of gene mutations in the tyrosine kinase domain of EGFR [6,7]. The EGFR mutations in lung cancer associated with sensitivity to EGFRTKIs occur more frequently in women, nonsmokers, Asians, and with adenocarcinomas [8,9].

Estrogen directly stimulates the transcription of estrogen-responsive genes of lung cells and transactivates the EGFR pathway. Stimulation of ER has been reported to increase the activity of the EGFR signal, and EGFR signal increases the activity of the ER [10]. Strong nuclear expression of ERß has been shown to be correlated with the presence of EGFR mutation, and the favorable prognostic significance of ERß expression has been shown to be influenced by the presence of EGFR mutation in lung adenocarcinoma [11]. However, to date, no report has described the correlation between mER $\alpha$ expression and EGFR mutation.

Based on these data from previous studies, we investigated the association between the expression of $\mathrm{mER} \alpha$ and EGFR mutation in lung adenocarcinoma. In addition, we restricted the tumor size of the adenocarcinomas to tumors measuring less than $3 \mathrm{~cm}$ in diameter, because EGFR mutation is considered an early event in the pathogenesis of lung adenocarcinoma [12]. The purpose of this study was to clarify the correlations between the expression of $\mathrm{mER} \alpha$ and EGFR mutation and clinicopathological factors, in relation to the prognosis of the patients. In addition, using immunohistochemistry to determine the expression of vascular endothelial growth factor (VEGF) and $\mathrm{Ki}-67$, we studied the tumor proliferative activity and angiogenesis in adenocarcinomas showing mER $\alpha$ expression and EGFR mutation.

\section{Methods}

\section{Study population}

Fifty-one patients with lung adenocarcinoma measuring less than $3 \mathrm{~cm}$ in diameter, who underwent surgical resection (lobectomy or segmentectomy) with systematic lymph node dissection, at the Kawasaki Medical School Hospital between 2007 and 2009 were enrolled in this study. None of the patients had received either radiotherapy or chemotherapy prior to surgery. The histological diagnosis of the tumors was based on the criteria of the World Health Organization, and the tumor, nodule, metastasis (TNM) stage was determined according to the criteria in 2009. Written informed consent was obtained from each patient for the study of the excised tissue samples from the surgical specimens. This study was conducted with the approval of the institutional Ethics Committee of Kawasaki Medical School. Follow-up information up to recurrence, or March 2012, was obtained from medical records.

All patients underwent fluorodeoxyglucose positron emission tomography (FDG-PET) before the surgery. The PET and computer tomography (CT) examinations were performed with a dedicated PET/CT scanner (Discovery ST Elite; GE Healthcare, Japan), at 115 minutes after intravenous injection of 150 to $220 \mathrm{MBq}$ of ${ }^{18} \mathrm{FDG}$ (FDGscan, Universal Giken, Nihon Mediphysics, Tokyo, Japan). The regions of interest (ROI) were placed three-dimensionally over the lung cancer nodules. Semiquantitative analysis of the images was performed by measuring the maximal standardized uptake value $\left(\mathrm{SUV}_{\max }\right)$ of the lesions.

\section{EGFR mutation analysis}

Analysis to detect EGFR mutations was performed in the resected, paraffin-embedded lung cancer tissues by a peptide nucleic acid-locked nucleic acid (PNA-LNA) PCR clamp method [13]. For this study, the PNA-LNA PCR clamp assay was performed at Mitsubishi Kagaku Bio-clinical Laboratories, Inc, Tokyo, Japan.

\section{Table 1 The patient characteristics}

\begin{tabular}{|c|c|c|}
\hline Characteristics & Number of patients & $\%$ \\
\hline \multicolumn{3}{|l|}{ Age } \\
\hline$<70$ & 31 & 60 \\
\hline$\geq 70$ & 20 & 40 \\
\hline \multicolumn{3}{|l|}{ Sex } \\
\hline Male & 23 & 48 \\
\hline Female & 28 & 52 \\
\hline \multicolumn{3}{|c|}{ Tumor differentiation } \\
\hline well & 32 & 68 \\
\hline moderate & 14 & 22 \\
\hline poor & 5 & 10 \\
\hline \multicolumn{3}{|c|}{ Lymphnode metastasis } \\
\hline negative & 43 & 87 \\
\hline positive & 8 & 13 \\
\hline \multicolumn{3}{|c|}{ Pathological stage } \\
\hline IA & 32 & 62 \\
\hline IB & 11 & 22 \\
\hline$\|(A+B)$ & 3 & 6 \\
\hline$\| I(A+B)$ & 5 & 10 \\
\hline \multicolumn{3}{|c|}{ Adjuvant chemotherapy } \\
\hline Yes & 13 & 35 \\
\hline No & 38 & 65 \\
\hline
\end{tabular}


Table 2 Association of membrane-bound ERa (mERa) expression / EGFR mutation status and clinicopathological variables

\begin{tabular}{|c|c|c|c|c|c|c|c|}
\hline \multirow[b]{2}{*}{ Characteristics } & \multicolumn{4}{|c|}{ mERa expression } & \multicolumn{3}{|c|}{ EGFR mutation } \\
\hline & $\mathrm{n}$ & Negative & Positive & $\overline{p \text {-value }}$ & Mutant & Wild & $\mathrm{p}$-value \\
\hline Patients, number & 51 & 27 & 24 & & 26 & 25 & \\
\hline Age(mean), year & & 66.6 & 66.4 & 0.717 & 67.5 & 65.4 & 0.391 \\
\hline Sex & & & & 0.921 & & & 0.036 \\
\hline Male & 23 & 12 & 11 & & 8 & 15 & \\
\hline Female & 28 & 15 & 13 & & 18 & 10 & \\
\hline Smoking & & & & 0.615 & & & 0.124 \\
\hline smoker & 21 & 12 & 9 & & 8 & 13 & \\
\hline never-smoker & 30 & 15 & 15 & & 18 & 12 & \\
\hline Tumor size(mean), mm & & 20.1 & 23.6 & 0.051 & 24.1 & 19.4 & 0.017 \\
\hline PET SUVmax & & 4.16 & 8.00 & 0.005 & 4.94 & 5.01 & 0.711 \\
\hline Tumor differentiation & & & & 0.019 & & & 0.691 \\
\hline well & 32 & 21 & 11 & & 17 & 15 & \\
\hline moderate/poor & 19 & 6 & 13 & & 9 & 10 & \\
\hline Vascular invasion & & & & 0.001 & & & 0.006 \\
\hline negative & 35 & 21 & 11 & & 13 & 22 & \\
\hline positive & 16 & 3 & 13 & & 13 & 3 & \\
\hline
\end{tabular}

\section{Immunohistochemical staining}

Immunohistochemical analyses were performed in the resected, paraffin-embedded lung cancer tissues. After microtome sectioning $(4 \mu \mathrm{m})$, the slides were processed for staining using an automated immunostainer (Nexes; Ventana, Tucson, AZ, USA). The streptavidin-biotinperoxidase detection technique using diaminobenzidine as the chromogen was applied. The primary antibodies were used according to the manufacturer's instructions (ER $\alpha$ :, clone HC-20, Santa Cruz Biotechnology, Santa Cruz, CA, 1/500 dilution; VEGF:, clone A-20, Santa Cruz Biotechnology, Santa Cruz, CA, 1/300 dilution; Ki-67: clone MIB-1, Dako Cytomation, Kyoto, Japan, 1/100 dilution). The slides were examined by two investigators who had no knowledge of the corresponding clinicopathological data. The expression of each marker protein was examined and evaluated according to the original protocol reported previously.

$\mathrm{ER} \alpha$ expression was categorized into eight grades according to previously described immunohistological scores [14]. Initially, six degrees of the proportional scores for positive staining were assigned according to the proportion of positive tumor cells $(0$, none; $1,<1 / 100 ; 2,1$ / 100 to $1 / 10 ; 3,1 / 10$ to $1 / 3 ; 4 ; 1 / 3$ to $2 / 3 ; 5,>2 / 3$ ). Next, an intensity score was assigned, which represented the average intensity in the tumor cells showing positive tumor staining ( 0 , none; 1 , weak; 2 , intermediate; 3 , strong). The proportional and intensity scores were then added to obtain a total score, ranging from 0 to 8 . For the statistical analysis, ER $\alpha$ expression was judged as positive when the score was $\geq 4$. VEGF expression was judged as positive when more than $20 \%$ of the cancer cell cytoplasm showed positive staining [15]. The labeling index of Ki-67 was measured by determining the percentage of cells with positively stained nuclei. Ki-67 expression was judged as positive when more than $10 \%$ of the cancer cell nuclei showed positive staining [16].

\section{Statistical analysis}

Statistical analysis was performed for examining significant differences among the groups and possible correlations between presence/absence of $\mathrm{mER} \alpha$ expression/EGFR mutation and the clinicopathological features using Fisher's exact test or the chi square $\left(\chi^{2}\right)$ test as appropriate. An unpaired $t$-test was used for comparison of the continuous data. Multivariate analyses were performed using logistic regression analysis. To explore the association between recurrence-free survival (RFS) and the presence of $m E R \alpha$ expression/EGFR mutation, a Kaplan-Meier survival analysis was performed by stratifying significant predictor variables identified in the Cox proportional hazards model. All the statistical analyses were conducted using SPSS software (Version 17.0; SPSS Incorporation, Chicago, IL, USA). All statistical tests were two-sided, and probability values $<0.05$ were regarded as statistically significant.

\section{Results}

\section{Clinical characteristics}

The characteristics of the patients are summarized in Table 1 . The patients ranged in age from 46 to 83 years (mean, 66.8). There were 23 men and 28 women. The median follow-up period was 34 months (range 3 to 54 months). 


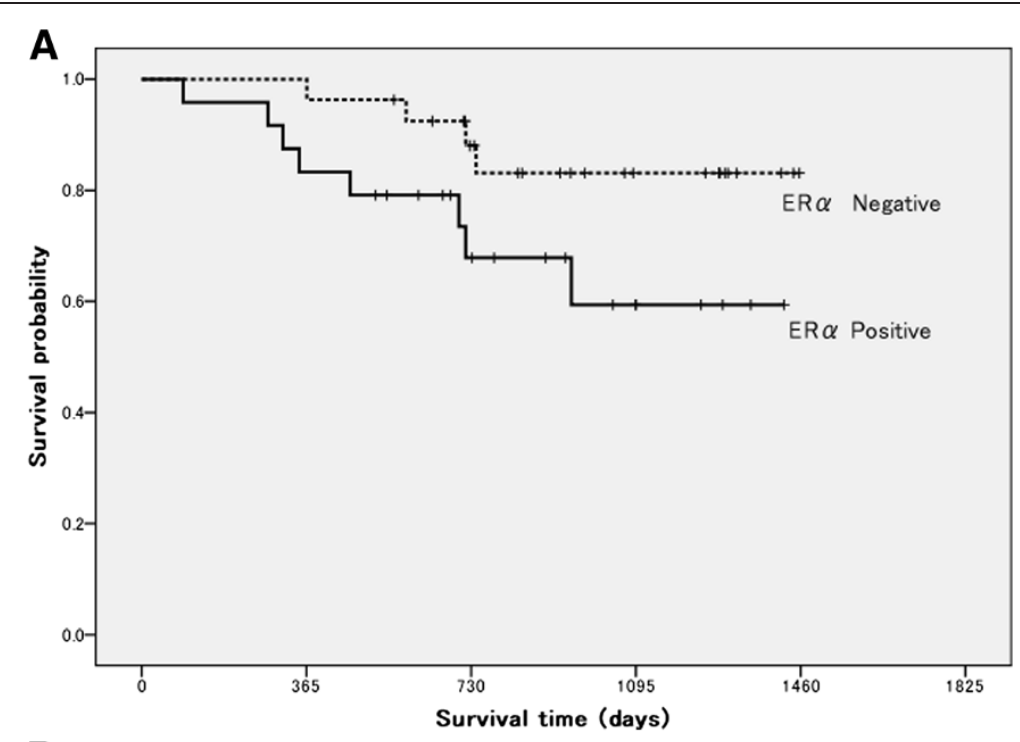

B

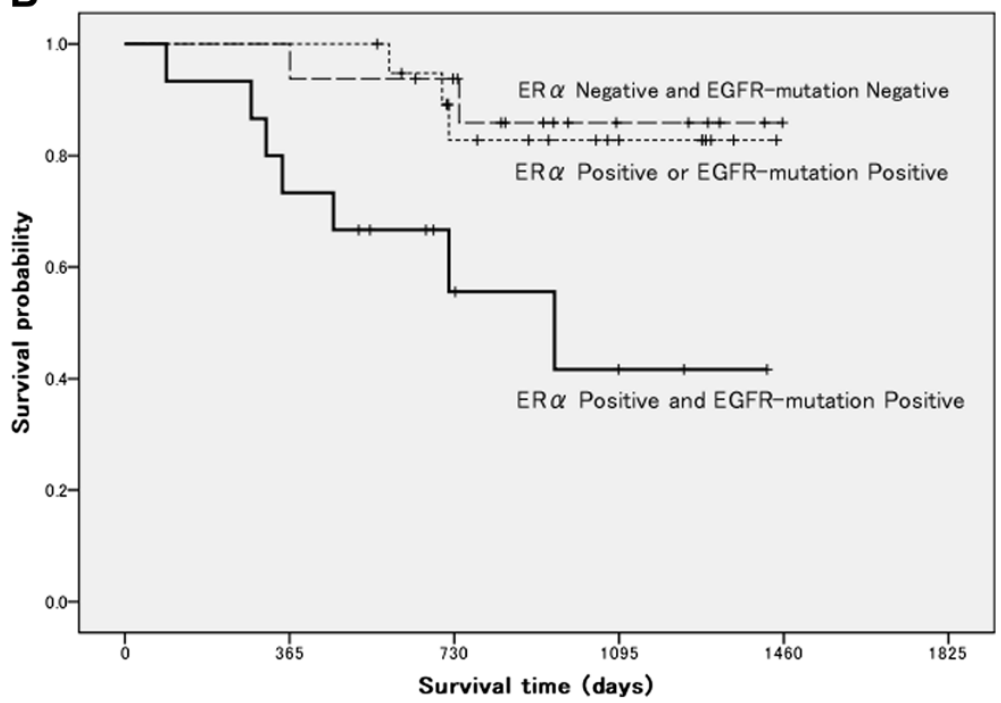

Figure 1 A. Kaplan-Meier curve for recurrence-free survival according to the presence or absence of membrane-bound ERa expression. The RFS tended to be worse in patients showing elevated mERa expression level in the tumor cells than that of the patients not showing tumor-cell mERa expression ( $P=0.076$, log-rank test). B. The RFS of the patients in the double-positive group was significantly worse than that of the other patients $(P=0.003$, log-rank test).

\section{Relationship between mERa expression and the clinicopathological characteristics}

Of the 51 patients, 24 exhibited marked increase of the immunoreactivity of the tumor cells for $\mathrm{mER} \alpha$, whereas the remaining 27 showed no increase of $\mathrm{mER} \alpha$ expression. Significant associations of the $\mathrm{mER} \alpha$ expression level in the tumor cells were observed with the tumor differentiation grade $(P=0.019)$, presence or absence of vascular invasion $(P=0.001)$, and the $\mathrm{SUV}_{\max }$ on FDGPET $(P=0.005)$, but not with age $(P=0.717)$, sex $(P=0.921)$, smoking status $(P=0.615)$ or tumor size $(P=0.051)$ (Table 2). The RFS tended to be worse in patients showing elevated $\mathrm{mER} \alpha$ expression level in the tumor cells than that of the patients not showing tumorcell $\mathrm{mER} \alpha$ expression; however, the association was not statistically significant $(P=0.076, \log$-rank test; Figure $1 \mathrm{~A})$.

\section{Relationship between the mutation status of EGFR and the clinicopathological characteristics}

Of the 51 patients, 26 had EGFR mutation, whereas the remaining 25 had wild-type EGFR. Significant associations of the EGFR mutation status were observed with sex $(P=0.036)$, tumor size $(P=0.017)$ and presence or absence of vascular invasion $(P=0.006)$, but not with age $(P=0.319)$, smoking status $(P=0.124), \mathrm{SUV}_{\max }$ on 
Table 3 Relationship between membrane-bound ERa (mERa) expression or EGFR mutation and VEGF or Ki-67 expression

\begin{tabular}{|c|c|c|c|c|c|c|}
\hline \multirow[b]{2}{*}{ Factor } & \multicolumn{3}{|c|}{ mERa expression } & \multicolumn{3}{|c|}{ EGFR mutation } \\
\hline & Negative & Positive & $p$-value & Mutant & Wild & $p$-value \\
\hline \multicolumn{7}{|l|}{ VEGF } \\
\hline negative & 17 & 2 & $<0.001$ & 9 & 10 & 0.691 \\
\hline positive & 10 & 22 & & 17 & 15 & \\
\hline \multicolumn{7}{|l|}{ Ki-67 } \\
\hline negative & 21 & 8 & 0.001 & 13 & 16 & 0.313 \\
\hline positive & 6 & 16 & & 13 & 9 & \\
\hline
\end{tabular}

FDG-PET $(P=0.711)$ or tumor differentiation grade $(P=0.691)$ (Table 2).

Associations of mERa expression and EGFR mutation with VEGF and Ki-67 expression

$\mathrm{mER} \alpha$ expression was significantly correlated with VEGF expression $(P<0.001)$ and Ki-67 expression $(P=0.001)$. However, the presence of EGFR mutation was not correlated with either VEGF expression or Ki-67 expression (Table 3).

Relationships between mERa expression, EGFR mutation and clinicopathological characteristics

We categorized the 51 patients according to the presence or absence of mER $\alpha$ expression and EGFR mutation status
Table 5 Prognostic value of recurrence-free survival

\begin{tabular}{|c|c|c|c|c|}
\hline \multirow[t]{2}{*}{ Variable } & \multicolumn{2}{|c|}{ Univariate analysis } & \multicolumn{2}{|c|}{ Multivariate analysis } \\
\hline & $\begin{array}{l}\text { Unfavorable } \\
\text { / favorable }\end{array}$ & $p$-value & $\begin{array}{l}\mathrm{HR} \\
(95 \% \mathrm{Cl})\end{array}$ & p-value \\
\hline Sex & $\begin{array}{l}\text { male } \\
\text { / female }\end{array}$ & 0.821 & & \\
\hline $\begin{array}{l}\text { Tumor } \\
\text { differentiation }\end{array}$ & $\begin{array}{l}\text { moderate+poor } \\
/ \text { well }\end{array}$ & 0.006 & $\begin{array}{l}1.96 \\
(0.77-5.00) \\
\end{array}$ & 0.157 \\
\hline $\begin{array}{l}\text { Pathological } \\
\text { stage }\end{array}$ & $\begin{array}{l}\mathrm{IB}-\| \mathrm{I} A \\
/ \mathrm{AA}\end{array}$ & 0.005 & $\begin{array}{l}2.74 \\
(0.63-11.83) \\
\end{array}$ & 0.178 \\
\hline double positive & Yes/ No & 0.003 & $\begin{array}{l}4.02 \\
(1.13-14.22)\end{array}$ & 0.031 \\
\hline
\end{tabular}

double positive: membrane-bound ERa expression positive and EGFR mutation positive.

HR: hazard ratio.

95\%Cl: 95\% confidence interval.

as follows: Group-1 $(\mathrm{n}=15)$ : both $\mathrm{mER} \alpha$ expression and EGFR mutation (double-positive); Group-2 $(\mathrm{n}=20)$ : either $\mathrm{mER} \alpha$ expression or EGFR mutation (single-positive); Group-3 ( $\mathrm{n}=16)$ : neither $\mathrm{mER} \alpha$ expression nor EGFR mutation (double-negative). Significant association of the double-positive status was observed with sex $(P=0.036)$, presence of vascular invasion $(P<0.001)$, VEGF expression $(P=0.018)$ and Ki-67 expression $(P=0.003)$, but not with age $(P=0.097)$, tumor differentiation grade $(P=0.150)$, $\mathrm{SUV}_{\text {max }}$ on FDG-PET $(P=0.168)$ (Table 4$)$. The RFS of the patients in the double-positive group was significantly worse than that of the other patients $(P=0.003$, log-rank test; Figure 1B).

Table 4 Relation among membrane-bound ERa (mERa) expression, EGFR mutation and clinicopathological characteristics

\begin{tabular}{|c|c|c|c|c|}
\hline Characteristics & $\begin{array}{l}\text { mERa negative } \\
\& E G F R \text { wild }\end{array}$ & $\begin{array}{l}\text { mERa positive } \\
\text { or EGFR mutant }\end{array}$ & $\begin{array}{l}\text { mERa positive } \\
\& E G F R \text { mutant }\end{array}$ & $p$-value \\
\hline Patients, number & 16 & 20 & 15 & \\
\hline Age (mean), year & 67.9 & 63.7 & 69.7 & 0.097 \\
\hline \multicolumn{5}{|l|}{ Sex } \\
\hline Male & 23 & 8 & 15 & 0.036 \\
\hline Female & 28 & 18 & 10 & \\
\hline PET SUVmax & 5.03 & 5.34 & 7.77 & 0.168 \\
\hline Tumor differentiation & & & & 0.150 \\
\hline well & 11 & 17 & 7 & \\
\hline moderate+poor & 5 & 3 & 8 & \\
\hline Vascular invasion & & & & $<0.001$ \\
\hline negative & 15 & 16 & 4 & \\
\hline positive & 1 & 4 & 11 & \\
\hline VEGF expression & & & & 0.018 \\
\hline negative & 10 & 7 & 2 & \\
\hline positive & 6 & 13 & 13 & \\
\hline Ki-67 expression & & & & 0.003 \\
\hline negative & 11 & 15 & 3 & \\
\hline positive & 5 & 5 & 12 & \\
\hline
\end{tabular}


A univariate analysis revealed that tumor differentiation grade $(P=0.006)$, pathological stage $(P=0.005)$ and double-positive status $(P=0.003)$ were independent risk factors influencing the RFS. However, a multivariate analysis identified only double-positive status as an independent risk factor influencing the RFS $(P=0.031)$ (Table 5).

\section{Discussion}

There have been several reports of cross-talk between ER (ER $\alpha$ or ERß) and EGFR status (protein expression or gene mutation). This is the first report focusing on $\mathrm{mER} \alpha$ and EGFR mutation. In the present study, we found that patients with lung adenocarcinoma who had both $\mathrm{mER} \alpha$ expression and EGFR mutation showed significantly poorer outcomes.

One of the factors peculiar to sex reported to be involved in lung cancer development is estrogen. For example, treatment with estrogen plus progestin in postmenopausal women did not increase the incidence of lung cancer, but increased the number of deaths from lung cancer, in particular deaths from non-small-cell lung cancer (NSCLC) [17]. ER enhances transcription in response to estrogens by binding to estrogen response elements and utilizing activator protein sites $[18,19]$. $E R \alpha$ exerts an augmenting effect on cell proliferation. On the other hand, ERß exerts a suppressive effect on cell proliferation via inhibition of ER $\alpha$ transcriptional activity $[20,21]$. The differential roles of $E R \alpha$ and $\beta$ in lung carcinogenesis and their biological properties are still controversial. In our study, $\mathrm{mER} \alpha$ expression was significantly correlated with VEGF and Ki-67 expression. Therefore, we suggest that $m E R \alpha$ may exert an augmenting effect on angiogenesis and cell proliferation.

Some recent studies have suggested the existence of bidirectional signaling between EGFR and ER [22,23]. In addition, two clinical studies have suggested the existence of cross-talk between ER and EGFR. First, Kawai et al. demonstrated that the combined overexpression of mER $\alpha$ and EGFR protein in patients with NSCLC was predictive of poorer outcomes [24]. They showed that while overexpression of either $\mathrm{mER} \alpha$ or EGFR was also predictive of poor outcomes, combined overexpression of $m E R \alpha$ and EGFR was an independent prognostic factor, suggesting the existence of cross-talk between $\mathrm{mER} \alpha$ and EGFR. Overexpression of EGFR has been observed and its prognostic significance confirmed in various cancers. In NSCLC, Salvaggi et al. showed that overexpression of EGFR was correlated with a poor prognosis [25]. However, the factor that is most strongly associated with from EGFR-TKI therapy has been identified as EGFR mutation, but not EGFR protein expression [9]. In the present study, for the treatment of patients with NSCLC, we studied EGFR mutation but not EGFR protein expression. Second, Nose et al. demonstrated that the favorable prognostic significance of overexpression of ERß was influenced by the presence of EGFR mutation in lung adenocarcinoma [11]. They showed that the status of EGFR mutation did not affect the RFS, but that $E R ß$ expression was associated with a favorable prognosis. To date, several studies have identified ER as a prognostic factor in lung cancer. In general, ER $\alpha$ expression seems to be associated with a poor prognosis, and ERß expression with a favorable prognosis [14,24,26-28].

An important finding of the present study was that $m E R \alpha$ expression and the categorized status of $E R \alpha$ expression/EGFR mutation was significantly correlated with the expression of Ki-67 and VEGF. Immunostaining with the Ki-67 antibody is a widely accepted method for evaluating the proliferative activity in a variety of human tumors. Tumors showing a high expression index of Ki-67 are frequently more aggressive than tumors showing a low Ki-67 expression index [16]. On the other hand, the VEGF family of proteins modulates angiogenesis, which is essential for tumor growth and metastasis. Expression of VEGF has been shown to be associated with tumor angiogenesis, metastasis, and prognosis in several cancers, including NSCLC [15]. To the best of our knowledge, no reports to date have shown a correlation between the expression of ER and VEGF or Ki-67. Our results using tissues from patients with lung adenocarcinoma tumors measuring less than $3 \mathrm{~cm}$ in diameter indicate that double marker positivity was significantly correlated with the expression of Ki-67 and VEGF.

\section{Conclusions}

This study demonstrated that the presence of $m E R \alpha$ expression together with EGFR mutation is an independent prognostic factor in patients with lung adenocarcinoma, suggesting the existence of cross-talk between mER $\alpha$ expression and EGFR mutation.

\section{Abbreviations}

CT: Computer tomography; EGFR: Epidermal growth factor receptor; EGFR-TKI: EGFR tyrosine kinase inhibitor; ER: Estrogen receptor; FDG-PET: Fluorodeoxyglucose positron emission tomography; mERa: Membrane-bound estrogen receptor; NSCLC: Non-small-cell lung cancer; PCR: Polymerase chain reaction; PNA-LNA: peptide nucleic acid-locked nucleic acid; RFS: Recurrence-free survival; ROI: Regions of interest; SUV $V_{\text {max }}$ : maximal standardized uptake value; TNM: Tumor, nodule, metastasis; VEGF: Vascular endothelial growth factor.

\section{Competing interests}

The authors declare that they have no competing interests.

\section{Authors' contributions}

Study concept and design: KS, MN. Data acquisition: SS, AM, KY. Data analysis and interpretation: KS, TY. Statistical analysis: KS, YH. Manuscript preparation: KS Manuscript review: MN. All authors have read and approved the final manuscript.

Acknowledgements

The authors thank Keiko Isoda for her technical assistance. 
Received: 6 April 2012 Accepted: 29 June 2012

Published: 11 July 2012

\section{References}

1. Gazdar AF, Thun MJ: Lung cancer, smoke exposure, and sex. $J$ Clin Oncol 2007, 25:469-471.

2. Radzikowska E, Głaz P, Roszkowski K: Lung cancer in women: age, smoking, histology, performance status, stage, initial treatment and survival. Population-based study of 20561 cases. Ann Oncol 2002, 13:1087-1093.

3. Osborne CK, Yochmowitz MG, Knight WA, McGuire WL: The value of estrogen and progesterone receptors in the treatment of breast cancer. Cancer 1980, 46:2884-2888.

4. Stabile LP, Davis AL, Gubish CT, Hopkins TM, Luketich JD, Christie N, Finkelstein S, Siegfried JM: Human non-small cell lung tumors and cells derived from normal lung express both estrogen receptor alpha and beta and show biological responses to estrogen. Cancer Res 2002, 62:2141-2450

5. Fujiwara K, Kiura K, Ueoka H, Tabata M, Hamasaki S, Tanimoto M: Dramatic effect of ZD1839 ("Iressa") in a patient with advanced non-small lung cancer and poor performance status. Lung Cancer 2003, 40:73-76.

6. Paez JG, Janne PA, Lee JC, Tracy S, Greulich H, Gabriel S, Herman P, Kaye FJ, Lindeman N, Boggon TJ, Naoki K, Sasaki H, Fujii Y, Eck MJ, Sellers WR, Johnson BE, Meyerson M: EGFR mutations in lung cancer: correlation with clinical response to gefitinib therapy. Science 2004, 304:1497-1500.

7. Lynch TJ, Bell DW, Sordella R, Gurubhagavatula S, Okimoto RA, Brannigan BW, Harris PL, Haserlat SM, Supko JG, Haluska FG, Louis DN, Christiani DC, Settleman J, Haber DA: Activating mutations in the epidermal growth factor receptor underlying responsiveness of non-small-cell lung cancer to gefitinib. N Engl J Med 2004, 350:2129-2139.

8. Mitsudomi T, Kosaka T, Endoh H, Horio Y, Hida T, Mori S, Hatooka S, Shinoda M, Takahashi T, Yatabe $Y$ : Mutations of the epidermal growth factor receptor gene predict prolonged survival after gefitinib treatment in patients with non-small-cell lung cancer with postoperative recurrence. J Clin Oncol 2005, 23:2513-2520.

9. Mok TS, Wu YL, Thongprasert S, Yang CH, Chu DT, Saijo N, Sunpaweravong P, Han B, Margono B, Ichinose Y, Nishiwaki Y, Ohe Y, Yang JJ,

Chewaskulyong B, Jiang H, Duffield EL, Watkins CL, Armour AA, Fukuoka M: Gefitinib or carboplatin-paclitaxel in pulmonary adenocarcinoma. N Engl J Med 2009, 361:947-957.

10. Pietras RJ, Marquez-Garban DC: Membrane-associated estrogen receptor signaling pathways in human cancers. Clin Cancer Res 2007, 13:4672-4676.

11. Nose N, Sugio K, Oyama T, Nozoe T, Uramoto H, Iwata T, Onitsuka T, Yasumoto K: Association between estrogen receptor-beta expression and epidermal growth factor receptor mutation in the postoperative prognosis of adenocarcinoma of the lung. J Clin Oncol 2009, 27:411-417.

12. Ji H, Li D, Chen L, Shimamura T, Kobayashi S, McNamara K, Mahmood U, Mitchell A, Sun Y, Al-Hashem R, Chirieac LR, Padera R, Bronson RT, Kim W, Jänne PA, Shapiro Gl, Tenen D, Johnson BE, Weissleder R, Sharpless NE, Wong KK: The impact of human EGFR kinase domain mutations on lung tumorigenesis and in vivo sensitivity to EGFR-targeted therapies. Cancer Cell 2006, 9:485-495

13. Nagai $Y$, Miyazawa $H$, Huqun Tanaka T, Udagawa $K$, Kato M, Fukuyama S, Yokote A, Kobayashi K, Kanazawa M, Hagiwara K: Genetic heterogeneity of the epidermal growth factor receptor in non-small cell lung cancer cell lines revealed by a rapid and sensitive detection system, the peptide nucleic acid-locked nucleic acid PCR clamp. Cancer Res 2005, 65:7276-7282

14. Kawai H, Ishii A, Washiya K, Konno T, Kon H, Yamaya C, Ono I, Minamiya Y Ogawa J: Estrogen receptor alpha and beta are prognostic factors in non-small cell lung cancer. Clin Cancer Res 2005, 11:5084-5089.

15. Han H, Silverman JF, Santucci TS, Macherey RS, d'Amato TA, Tung MY, Weyant RJ, Landreneau RJ: Vascular endothelial growth factor expression in stage I non-small cell lung cancer correlates with neoangiogenesis and a poor prognosis. Ann Surg Oncol 2001, 8:72-79

16. Martin B, Paesmans M, Mascaux C, Berghmans T, Lothaire P, Meert AP, Lafitte JJ, Sculier JP: Ki-67 expression and patients survival in lung cancer: systematic review of the literature with meta-analysis. Br J Cancer 2004 . 91:2018-2025

17. Chlebowski RT, Schwartz AG, Wakelee H, Anderson GL, Stefanick ML, Manson JE, Rodabough RJ, Chien JW, Wactawski-Wende J, Gass M, Kotchen
JM, Johnson KC, O'Sullivan MJ, Ockene JK, Chen C, Hubbell FA: Oestrogen plus progestin and lung cancer in postmenopausal women (Women's Health Initiative trial): a post-hoc analysis of a randomised controlled trial. Lancet 2009, 374:1243-1251.

18. Kushner PJ, Agard DA, Greene GL, Scanlan TS, Shiau AK, Uht RM, Webb P: Estrogen receptor pathways to AP-1. J Steroid Biochem Mol Biol 2000 74:311-317.

19. Webb P, Nguyen P, Valentine C, Lopez GN, Kwok GR, Mclnerney E, Katzenellenbogen BS, Enmark E, Gustafsson JA, Nilsson S, Kushner PJ: The estrogen receptor enhances AP-1 activity by two distinct mechanisms with different requirements for receptor transactivation functions. Mol Endocrinol 1999, 13:1672-1685.

20. Paech K, Webb P, Kuiper GG, Nilsson S, Gustafsson J, Kushner PJ, Scanlan TS: Differential ligand activation of estrogen receptors ERalpha and ERbeta at AP1 sites. Science 1997, 277:1508-1510.

21. Hall JM, McDonnell DP: The estrogen receptor beta-isoform (ERbeta) of the human estrogen receptor modulates ERalpha transcriptional activity and is a key regulator of the cellular response to estrogens and antiestrogens. Endocrinology 1999, 140:5566-5578.

22. Levin ER: Bidirectional signaling between the estrogen receptor and the epidermal growth factor receptor. Mol Endocrinol 2003, 17:309-317.

23. Schiff R, Massarweh SA, Shou J, Bharwani L, Mohsin SK, Osborne CK Cross-talk between estrogen receptor and growth factor pathways as a molecular target for overcoming endocrine resistance. Clin Cancer Res 2004, 10:331-336.

24. Kawai H, Ishii A, Washiya K, Konno T, Kon H, Yamaya C, Ono I, Ogawa J: Combined overexpression of EGFR and estrogen receptor alpha correlates with a poor outcome in lung cancer. Anticancer Res 2005, 25:4693-4698.

25. Selvaggi G, Novello S, Torri V, Leonardo E, De Giuli P, Borasio P, Mossetti C, Ardissone F, Lausi P, Scagliotti GV: Epidermal growth factor receptor overexpression correlates with a poor prognosis in completely resected non-small-cell lung cancer. Ann Oncol 2004, 15:28-32.

26. Schwartz AG, Prysak GM, Murphy V, Lonardo F, Pass H, Schwartz J, Brooks S: Nuclear estrogen receptor beta in lung cancer: expression and survival differences by sex. Clin Cancer Res 2005, 11:7280-7287.

27. Wu CT, Chang YL, Shih JY, Lee YC: The significance of estrogen receptor beta in 301 surgically treated non-small cell lung cancers. J Thorac Cardiovasc Surg 2005, 130:979-986.

28. Skov BG, Fischer BM, Pappot H: Oestrogen receptor beta over expression in males with non-small cell lung cancer is associated with better survival. Lung Cancer 2008, 59:88-94.

doi:10.1186/1477-7819-10-141

Cite this article as: Shimizu et al:: Membrane-bound estrogen receptor-a expression and epidermal growth factor receptor mutation are associated with a poor prognosis in lung adenocarcinoma patients. World Journal of Surgical Oncology 2012 10:141

\section{Submit your next manuscript to BioMed Central and take full advantage of:}

- Convenient online submission

- Thorough peer review

- No space constraints or color figure charges

- Immediate publication on acceptance

- Inclusion in PubMed, CAS, Scopus and Google Scholar

- Research which is freely available for redistribution 